\title{
Inactivation of viable Ascaris eggs during faecal sludge co-composting with chicken feathers and market waste
}

\author{
M. Manga ${ }^{a, b, c, *}$, M.A. Camargo-Valero ${ }^{b}$, B.E. Evans ${ }^{b, d}$ \\ ${ }^{a}$ The Water Institute at UNC, Department of Environment Sciences and Engineering, University of North Carolina at Chapel Hill, \\ 4114 McGavran Hall, Campus Box \#7431, NC 27599, Chapel Hill, North Carolina, USA, Tel. +1 919803 3581; \\ emails: musamanga@cedat.mak.ac.ug/mmanga@email.unc.edu (M. Manga) \\ ${ }^{b}$ BioResource Systems Research Group, School of Civil Engineering, University of Leeds, Leeds LS2 9JT, UK, Tel. +44 (0)113 3432269 ; \\ emails: B.E.Evans@leeds.ac.uk (B.E.Evans), M.A.Camargo-Valero@leeds.ac.uk (M.A. Camargo-Valero) \\ 'Department of Construction Economics and Management, College of Engineering, Design, Art, and Technology (CEDAT), \\ Makerere University, P.O. Box: 7062, Kampala, Uganda, Tel. +256-702-965158 \\ ${ }^{d}$ Departamento de Ingeniería Química, Universidad Nacional de Colombia, Campus La Nubia, Manizales, Colombia
}

Received 24 December 2016; Accepted 4 June 2019

\section{A B S T R A C T}

Faecal Sludge (FS) contains high concentrations of pathogenic microorganisms that are 10-100 times higher than those in domestic wastewater. Proper and sustainable treatment is required to inactivate these pathogens if FS is to be recycled in agriculture, so as to minimise public health and environmental risks. Composting is one of the common low-cost technologies of sanitising FS in Urban Africa; however, it is associated with longer pathogen inactivation periods that make it commercially uneconomical. This study investigated the effect of different organic wastes types and their mixing ratios with FS on the inactivation efficiency of viable Ascaris eggs (suum and lumbricoides) during composting. Dewatered FS was mixed with market waste (MW), chicken feathers (CF) and sawdust (SD) in different ratios. Compost piles of FS:MW:SD and FS:CF:SD both in volumetric ratios of 1:2:1 and 1:3:1 were set-up in duplicate $\left(3 \mathrm{~m}^{3}\right.$ each), composted and monitored weekly for viable Ascaris eggs presence for a period of 15 weeks. The results suggest that the organic waste types have a significant effect on the temperature evolution and pathogen inactivation efficiency while their mixing ratios do not. Piles containing CF achieved the shortest pathogen survival period of 4 weeks compared with 6-8 weeks for those with MW. The temperature-time factor was found to be the most important variable responsible for viable Ascaris eggs inactivation. However, other mechanisms such as microbial antagonism or antibiotic action induced by indigenous microorganisms and toxic by-products such as free ammonia were found to have also played an important role in Ascaris eggs inactivation. All piles attained $100 \%$ Ascaris eggs inactivation from FS, and therefore, the compost was safe for use in agriculture. The study findings suggest that composting of FS with CF can reduce Ascaris eggs inactivation periods by $42 \%$, which may thus reduce the operational costs of FS treatment facilities.

Keywords: Faecal sludge; Composting; Helminth eggs; Viable Ascaris eggs; Chicken feathers

\section{Introduction}

Sanitation service delivery in urban Africa comprises the use of on-site sanitation facilities together with conventional sewered systems. Indeed, on-site facilities have played a predominant role in the provision of sanitation services in informal urban areas, but unfortunately, faecal sludge (FS) management has not been harmonised with the needs of

\footnotetext{
* Corresponding author.
} 
the increasing urban populations. Consequently, FS is often collected from on-site sanitation installations and indiscriminately disposed of untreated into the environment (e.g., wetlands, drainage channels, etc.) leading to severe environmental and public health risks [1]. FS contains high concentrations of pathogenic microorganisms that are 10-100 times higher than those in domestic wastewater [2]. Proper and sustainable treatment is required to inactivate these pathogenic microorganisms to acceptable standards if FS is to be safely reused, for instance in agriculture ( $\leq 1$ egg per $4 \mathrm{~g}$ of total biosolids [3]). Literature has continuously reported helminth eggs especially Ascaris eggs as the most resistant excreted pathogen and therefore, it has been selected as the best pathogenic indicator to monitor FS composting processes [4-6]. Historical evidence has indicated that upon excretion, helminth eggs can survive for about 10-12 months under tropical climatic conditions [5].

Composting is one of the widely promoted ways of sanitising FS in urban Africa [7-9]. However, it is associated with both insufficient helminth eggs inactivation and longer inactivation periods, which makes its commercialisation uneconomical. For example, Koné et al. [10] found that helminth eggs (Ascaris eggs inclusive) are able to survive for approximately $80 \mathrm{~d}$ during the composting of FS with organic waste. Such inactivation periods are too long for commercialisation of FS compost. Cabañas-Vargas et al. [11] attained only $81 \%$ helminth eggs inactivation by the end of a 30-d composting period during the composting of sewage sludge and green waste. Moreover, little is known about the fate of Ascaris eggs during the composting of FS. Therefore, the aim of this study was to assess the effect of locally available organic wastes (i.e., chicken feathers, sawdust and market waste) and their mixing ratios with FS on the fate of viable Ascaris eggs during FS composting.

\section{Material and methods}

\subsection{Pilot-scale composting facility and raw material collection}

The study was conducted at a pilot-scale composting facility constructed at National Water and Sewerage Corporation (NWSC) faecal sludge treatment facility at Lubigi, Kampala, Uganda. This is at a geographical location of latitude $0^{\circ} 18^{\prime} 58^{\prime \prime} \mathrm{N}$, longitude $32^{\circ} 34^{\prime} 55^{\prime \prime} \mathrm{E}$ and elevation of $1,223 \mathrm{~m}$ above sea level. The pilot-scale composting facility had a total area of $300 \mathrm{~m}^{2}$, which comprised of both dewatering and composting sections. The composting section consisted of a roof covered composting platform sloping gently towards the leachate drainage channel. The detailed design and construction of the dewatering facility are presented in our previous work [12].

\subsection{Collection of faecal sludge and organic waste}

Raw FS used in this study was collected from the nearby Kampala informal settlements (i.e., Makerere Kikoni and Bwaise). FS from VIP latrines and septage from vaults and tanks was mixed in a ratio of 1:2 by volume (VIP latrine sludge: septage) and pre-treated by dewatering on sludge drying beds. Detailed work on FS dewatering and characterisation is also presented in our previous work [12].
Market waste and chicken feather waste were collected from Nakasero market and Kalerwe market, with the help of Kampala City Council Authority. The market waste consisted of vegetable, fruit and food waste as well as green waste such as twigs with leaves or small tree branches, which are usually used for covering and protecting vegetables, food or fruits from damage or sunrays while in transit. Sawdust was obtained from Bwaise sawmill located less than $0.5 \mathrm{~km}$ from the project site. Organic waste delivered to the composting facility was sorted to remove any inorganics and chopped into smaller pieces by hand (about $20-40 \mathrm{~mm}$ ) prior to mixing with dewatered FS and pile formation.

\subsection{Construction and monitoring of composting piles}

Dewatered FS of about $27 \%-35 \%$ total solids content was thoroughly mixed with sorted organic wastes and sawdust as the bulking agent. Four types of compost static piles each $3 \mathrm{~m}^{3}$ were constructed, each in duplicate: (i) SOS1 (1:2:1 v/v; dewatered sludge: market waste: sawdust); (ii) SOS2 (1:3:1 v/v; dewatered sludge: market waste: sawdust); (iii) SCS1 (1:2:1 v/v; dewatered sludge: chicken feathers: sawdust); (iv) SCS2 (1:3:1 v/v; dewatered sludge: chicken feathers: sawdust). The composting piles were aerated by manual turning, with a $7 \mathrm{~d}$ turning frequency. The composting temperature of each pile was measured daily at the: top (ca. $750 \mathrm{~mm}$ from the pile base), middle (400 $\mathrm{mm}$ from pile base) and bottom (200 $\mathrm{mm}$ from pile base), using a TFA (D-Wertheim, Model 19.2008) stainless steel body compost thermometer. The composting piles were monitored for a period of 15 weeks (air temperature: $19^{\circ} \mathrm{C}-26^{\circ} \mathrm{C}$; relative humidity: 69\%-80\%).

\subsection{Sampling methods}

\subsubsection{Dewatered faecal sludge sampling}

Dewatered sludge samples were collected from at least 10 randomly chosen sampling points on each drying bed before sludge removal. At each chosen location, the sludge was stirred until it was homogeneous prior to sample collection. An equal volume of sludge was collected from each sampling point, and all of these were thoroughly mixed to form a composite sample from which a portion was collected using quarter sampling. This sample was then analysed for total solids and presence of viable Ascaris eggs.

\subsubsection{Compost sampling}

Compost samples of about $400 \mathrm{~g}$ were collected from the top, middle and bottom as well as the outer and inner sections of each composting pile. To ensure representative sampling, the collected subsamples were then mixed homogeneously to form a composite sample for each of the four pile types, from which a sample of approximately $500 \mathrm{~g}$ was collected using quartering method, and taken for total solids and viable Ascaris eggs analysis. Samples were collected at day 0 and weekly from the composting piles until the end of the composting period. The analysis was carried out at Bugolobi NWSC central laboratory in Kampala. 


\subsection{Analytical methods}

\subsubsection{Total solids and moisture content}

A sample of $50 \mathrm{~g}$ was weighed into a previously weighed crucible. This was then dried in an oven at $105^{\circ} \mathrm{C}$ for $24 \mathrm{~h}$. It was removed thereafter, allowed to cool for $30 \mathrm{~min}$ and reweighed. A total solid and moisture content (\%) were then computed by using the sample initial and final weights [13].

\subsubsection{Ammonium}

Ammonium $\left(\mathrm{NH}_{4}-\mathrm{N}\right)$ was extracted with $0.5 \mathrm{M} \mathrm{K}_{2} \mathrm{SO}_{4}$ in $1: 10(\mathrm{w} / \mathrm{v})$ from fresh compost samples and determined by spectrophotometric methods according to procedures reported in the literature $[13,14]$.

\subsubsection{Respiration rate}

The microbial respiratory activity in compost samples was measured based on $\mathrm{CO}_{2}-\mathrm{C}$ evolution rate conducted in closed bottles according to Öhlinger [15] and Alef [16] soil respiration techniques, but with some modifications made to techniques based on similar soil respiration procedures reported in literature [17-21]. $\mathrm{CO}_{2}-\mathrm{C}$ was trapped in an alkaline solution $(\mathrm{KOH})$, which was then titrated with $\mathrm{HCl}$. $\mathrm{CO}_{2}-\mathrm{C}$ production rate was assessed and expressed as $\mathrm{mg}$ $\mathrm{CO}_{2}-\mathrm{C}$ per mass of organic matter (as volatile solids - VS) per day [22,23].

\subsubsection{Viable Ascaris eggs analysis}

Viable Ascaris eggs concentrations were analysed according to USEPA [3] technique with slight modifications made to it by other authors [24-26]. The method is based on a fundamental principle of recovering helminth eggs from compost or dewatered FS by floating them from other debris using $\mathrm{ZnSO}_{4}$ (with a comparatively relative density of 1.2-1.3) in a supernatant obtained by centrifugation. The relative density of 1.2 was used so that the Ascaris eggs with relative density of about 1.13 are able to float in the solution $[24,25]$. In this study, using a sample of $400 \mathrm{~g}$, a series of steps including washing, sedimentation, filtration, flotation and extraction were conducted so as to increase concentration of Ascaris eggs in the suspension. A filter of $35 \mu \mathrm{m}$ pore size was used for separation of helminth eggs (Ascaris eggs) from the supernatant [4]. For viability assessment, the highly concentrated suspension was then re-suspended in $4 \mathrm{~mL}$ of $0.1 \mathrm{~N}$ solution of sulphuric acid $\left(\mathrm{H}_{2} \mathrm{SO}_{4}\right)$ and then incubated for $21-28 \mathrm{~d}$ at $26^{\circ} \mathrm{C}$ or until when most of the ova were fully viable (embryonated) [3]. Thereafter, the incubated concentrates were examined microscopically (10× or $40 \times$ magnification). All the viable and non-viable (unembryonated) Ascaris eggs observed within the grid in both chambers of the McMaster slide were counted. Ova, where the larva was observed, were considered and counted as viable. In some cases, the larva was observed to be moving in viable Ascaris ova. The images in Fig. 1 were used as a guide in the identification of the viable and non-viable Ascaris eggs [24,26]. To minimise errors during egg counting, each sample was counted in triplicate and average values reported. The average counted viable eggs were then expressed as Ascaris eggs g ${ }^{-1}$ dry weight. For better analysis, these were further expressed as the percentage of initial viable eggs count.

\subsection{Statistical analysis}

Laboratory results were reported as mean values or \pm standard error of duplicates, and subjected to statistical analysis using IBM SPSS 21.0 software. Data were analysed using non-parametric Friedman test. The significance of differences amongst the mean values was tested at a level of $p=0.05$, with $95 \%$ confidence level. Spearman's rho test was also used for examining the correlation coefficient between parameters based on a $>95 \%$ confidence level. $p \leq 0.05$ was set as the statistical significance criterion. Standard multiple regression analysis was conducted according to Pallant [27], to determine the most important factors responsible for viable Ascaris eggs inactivation during composting.

\section{Results and discussion}

\subsection{Characterisation of raw materials}

In the present study, the average viable Ascaris eggs content of $37 \pm 16$ eggs $^{-1}$ dry weight observed in the dewatered FS compare well with those published by other authors $[10,28]$. However, these concentrations are 10-100 times higher than those found in sewage sludge [9]. This result

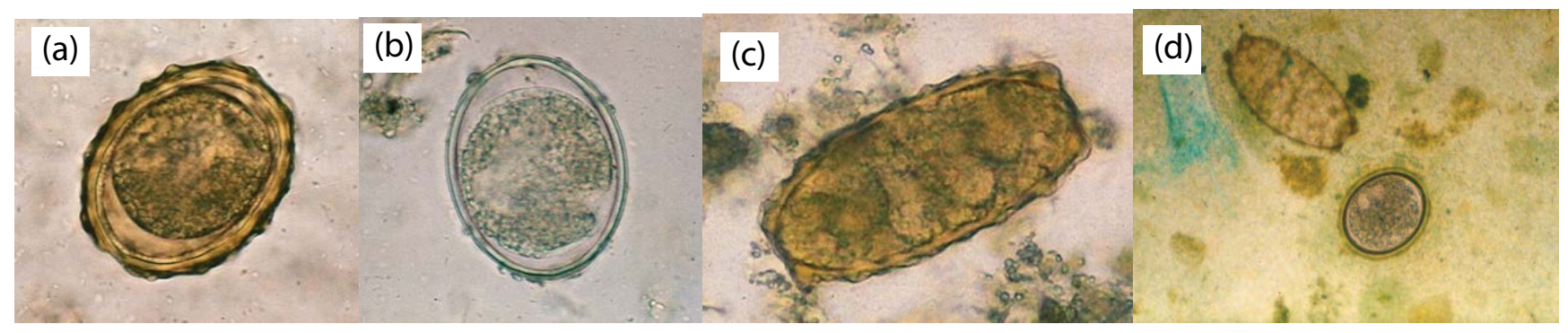

Fig. 1. (a) Normal fertile Ascaris lumbricoides ovum showing brownish coloured mamillated outer shell. Measures size: 55-75 × 35-50 $\mu \mathrm{m}$, (b) normal fertile Ascaris lumbricoides ovum but lacking mamillated layer referred to as "decorticated" egg, (c) infertile Ascaris ovum (these are longer and thinner than fertile eggs. They have brownish coloured grossly irregular mamillated layer and the egg contents are granular and disorganised [size: 85-95 $\times 43-47 \mu \mathrm{m}$ ]), and (d) fertile and infertile eggs of Ascaris lumbricoides in a Kato-Katz preparation. 
is not surprising especially in developing countries where helminth eggs are rampant [29]. Detailed work on characterisation of raw FS from VIP latrines and septic tanks as well as FS dewatering is presented in our previous work [12]. No Ascaris eggs were detected in the sawdust, market waste and chicken feathers waste samples. This implies that the solid wastes used in this study were free from Ascaris eggs or faecal contamination. Furthermore, the content of dry solids found in samples of market waste $(36.6 \% \pm 3.3 \%)$, chicken feathers $(39.3 \% \pm 0.5 \%)$ and sawdust $(68.8 \% \pm 5.9 \%)$ compared well with those reported by other authors $[7,28]$. Other physical and chemical characteristics of the organic wastes used in this study are presented in Table S1, and these have been extensively discussed in our previous work [30].

\subsection{Temperature evolution}

All the composting piles attained the composting temperatures $\left(\geq 55^{\circ} \mathrm{C}\right)$ and conditions suggested by USEPA [3] for effective pathogen inactivation during composting (Figs. 2a-d). Composting trials using SCS1 and SCS2 blends reached mean temperatures of $\geq 55^{\circ} \mathrm{C}$ within the shortest composting period of 7 and $5 \mathrm{~d}$, respectively (Figs. 2a and b). These temperatures were sustained within the SCS1 and SCS2 piles for a period of 42 and $35 \mathrm{~d}$, respectively, before they dropped to $50^{\circ} \mathrm{C}$. This implies that the composting feedstock supported the quick establishment of microbial activities within the composting piles, which could have been due to the availability of easily biodegradable organic materials (such as fats, starch and proteins) commonly found in chicken feather waste [31]. This also suggests that chicken feather waste, FS and sawdust are excellent complementary organic substances for co-composting. In some sections of SCS1 and SCS2 piles, temperatures as high as $70^{\circ} \mathrm{C}$ and $67^{\circ} \mathrm{C}$ were reached within a composting period of 11 and $5 \mathrm{~d}$, respectively. This implies that the composting material containing chicken feather wastes had an excellent selfinsulating characteristic. Self-insulating phenomenon is an important factor for the temperature increase in piles especially during the early composting stages, where the heat generated as a result of microbial activities is trapped within the composting piles [32,33].

In contrast, SOS1 and SOS2 piles required relatively longer composting periods of approximately 9 and $10 \mathrm{~d}$, respectively, to achieve the mean temperatures of $\geq 55^{\circ} \mathrm{C}$ (Figs. 2c and d). This might have been due to the presence of high proportion of recalcitrant carbon (e.g., lignin) and a low proportion of easily biodegradable carbon in the composting material, which may have limited the early microbial activities, and thus the rapid rise in the composting temperatures. Some previous studies have similarly found market waste/green waste to have contained low proportions of easily biodegradable carbon [34,35]. The shredded twigs, leaves and wood added to these composting piles may have contained high proportions of recalcitrant carbon (e.g., lignin). However, maximum temperatures of $65^{\circ} \mathrm{C}$ and $64^{\circ} \mathrm{C}$ were reached in some sections of SOS1 and SOS2 composting piles after 21 and $20 \mathrm{~d}$ composting period, respectively. The SOS1 and SOS2 piles maintained the optimum mean temperatures $\left(\geq 55^{\circ} \mathrm{C}\right)$ for effective pathogen inactivation for a short time of approximately 21 and $25 \mathrm{~d}$, respectively (Figs. 2c and d). This could perhaps be attributed to high heat losses from the composting piles to the environment as a result of energetic flux since these piles


Fig. 2. Temperature evolution during co-composting of faecal sludge with (a) chicken feather waste and sawdust in a ratio of 1:2:1 - SCS1, (b) chicken feather waste and sawdust in a ratio of 1:3:1 - SCS2, (c) organic market waste and sawdust in a ratio of 1:2:1 SOS1; and (d) organic market waste and sawdust in a ratio of 1:3:1 - SOS2. Error bars represent the standard deviation of the bottom, center, left side and right side pile temperatures for each composting pile. 
were observed to have turned more porous, especially after 6 weeks composting period.

The temperature profiles of four types of composting piles suggest that the different organic waste types had an influence on the composting temperatures. This was confirmed by the Friedman test results at 95\% confidence level, which indicated that the organic waste types had a statistically significant effect on the composting temperatures evolution with $p=0.0001$. This could be due to the difference in the characteristics of the biodegradable organic materials contained in the feedstock materials used. It is important to note that the SCS piles generally exhibited higher composting temperatures and longer thermophilic phase duration than the SOS piles during composting (Figs. 2a-d). This may have been due to the labile nature of the organic materials present in the SCS composting piles and their high thermal inertia [36].

As can be seen in Figs. 2a-d, SOS1 and SCS1 composting piles (of 1:2:1 mixing ratios) recorded slightly higher composting temperatures than SOS2 and SCS2 (of 1:3:1 mixing ratio). This clearly indicates that such piles contained more proportions of easily biodegradable organic materials (e.g., fats, sugars, proteins and starch) which may have been present in the dewatered FS, and favourable conditions for effective composting conditions. The increase in the mixing ratio of organic waste/chicken feathers to faecal sludge from 1:2:1 to $1: 3: 1$; (a) may have led to a dilution effect of readily available organic matter sources which may have been present in FS; (b) may have negatively affected the structure of the composting material by turning it extremely loose or porous, and thus leading to the heat diffusion to the environment. Lu et al. [37] similarly found low mixing ratios (1:3) of sewage sludge to municipal solid waste to have attained higher composting temperatures than higher mixing ratios (1:5 and 1:9). Surprisingly, Friedman test results at $95 \%$ confidence level showed that the mixing ratio did not have a significant effect on the temperature evolution.

\subsection{Moisture content evolution}

All the four organic waste compost types recorded high initial moisture content in the range of $62.0 \%$ and $66.0 \%$ (Fig. 3). However, this was within the suggested optimum moisture content range of $55 \%-70 \%$ for effective composting [38]. SCS1 and SCS2 composting piles exhibited a significant drop of approximately $16.5 \%$ and $17.7 \%$, respectively, in the initial moisture content (MC), within the early composting periods of 6 weeks (Fig. 3). This was then followed by an increase from $48.8 \%$ and $45.4 \%$, on week 6 to $52.2 \%$ and $50.0 \%$, respectively, on week 8 after re-wetting of the piles, and finally a gradual decrease to the final mean MC values of $44.0 \%$ and $43.0 \%$, respectively, at the end of the composting period. In contrast, SOS1 and SOS2 piles had different MC evolution trend, with significant fluctuations especially during the thermophilic phase. The MC descended sharply in the first week, then rose in the second week; then descended, and that behaviour continued until reaching the final MC of $39.0 \%$ and $44.0 \%$ at the end of the composting periods.

The decrease in moisture content exhibited by all the composting piles could be attributed to the high initial composting temperatures (Figs. 2a-d), that may have resulted into water vaporisation from the composting piles especially during the thermophilic phase. Similar behaviour has been reported by other authors [39]. However, moisture loss during composting has been suggested by Finstein et al. [40] as an index for assessing the decomposition rate of organic matter, since heat generated as a result of the decomposition process stimulates vaporisation. The increase in the MC may be attributed to moisture generated as a by-product of the intensive decomposing process of organic substances, and the water holding capacity of the composting material. It is important to note that the SOS piles (containing only organic market waste) exhibited higher moisture content than SCS piles, especially during the intensive composting periods. This could be attributed to the high biomass of the organic market waste in the composting feedstock, which may have resulted into the release of high water content as a metabolic end-product of the decomposition process of the most labile organic matter fractions. The final moisture content and dynamics observed in this study are comparable with those observed by other authors during the composting of different feedstock [18].

\subsubsection{Evolution of carbon dioxide $\left(\mathrm{CO}_{2}-\mathrm{C}\right)$}

Fig. 4a illustrates the evolution of $\mathrm{CO}_{2}-\mathrm{C}$ respiration rate exhibited by all composting piles during the FS composting with different organic waste. During the composting of SCS1 and SCS2 piles, the high initial $\mathrm{CO}_{2}-\mathrm{C}$ respiration rate mean values of 11.5 and $10.2 \mathrm{mg} \mathrm{CO}_{2}-\mathrm{C} \mathrm{g} \mathrm{VS}^{-1} \mathrm{~d}^{-1}$ decreased but with oscillations to mean values of 0.75 and $0.60 \mathrm{CO}_{2}-\mathrm{C}$ $\mathrm{g} \mathrm{VS}^{-1} \mathrm{~d}^{-1}$ by 14 weeks composting periods, respectively (Fig. 4a). In contrast, a sudden increase was observed in the respiration rates of SOS1 and SOS2 composting piles

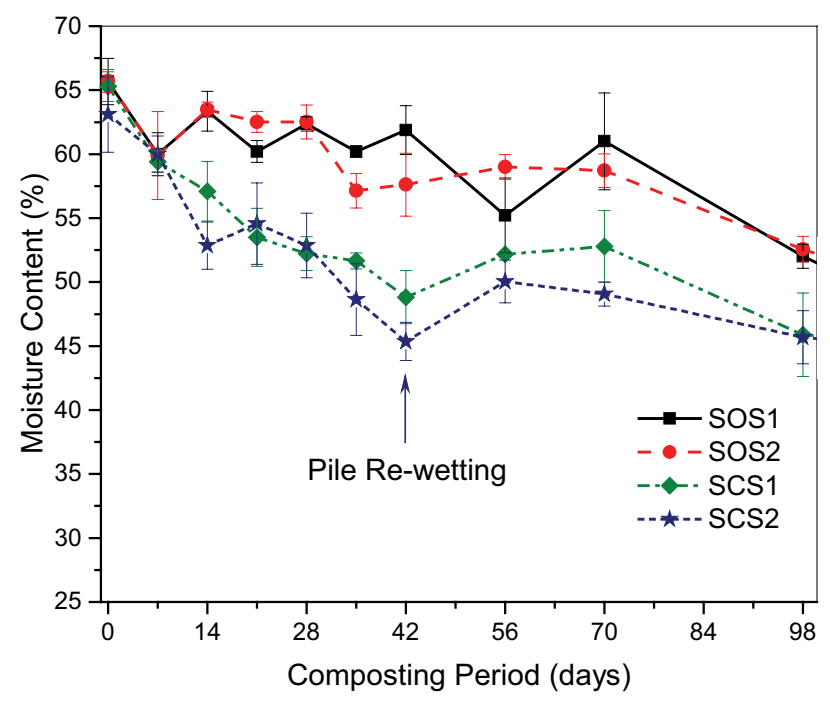

Fig. 3. Evolution of moisture content (MC) during the cocomposting of faecal sludge with: (a) chicken feather waste and sawdust in a ratio of 1:2:1 - SCS1, (b) chicken feather waste and sawdust in a ratio of 1:3:1 - SCS2, (c) organic market waste and sawdust in a ratio of 1:2:1 - SOS1, and (d) organic market waste and sawdust in a ratio of 1:3:1 - SOS2. Error bars represent the standard error for the duplicated piles. 

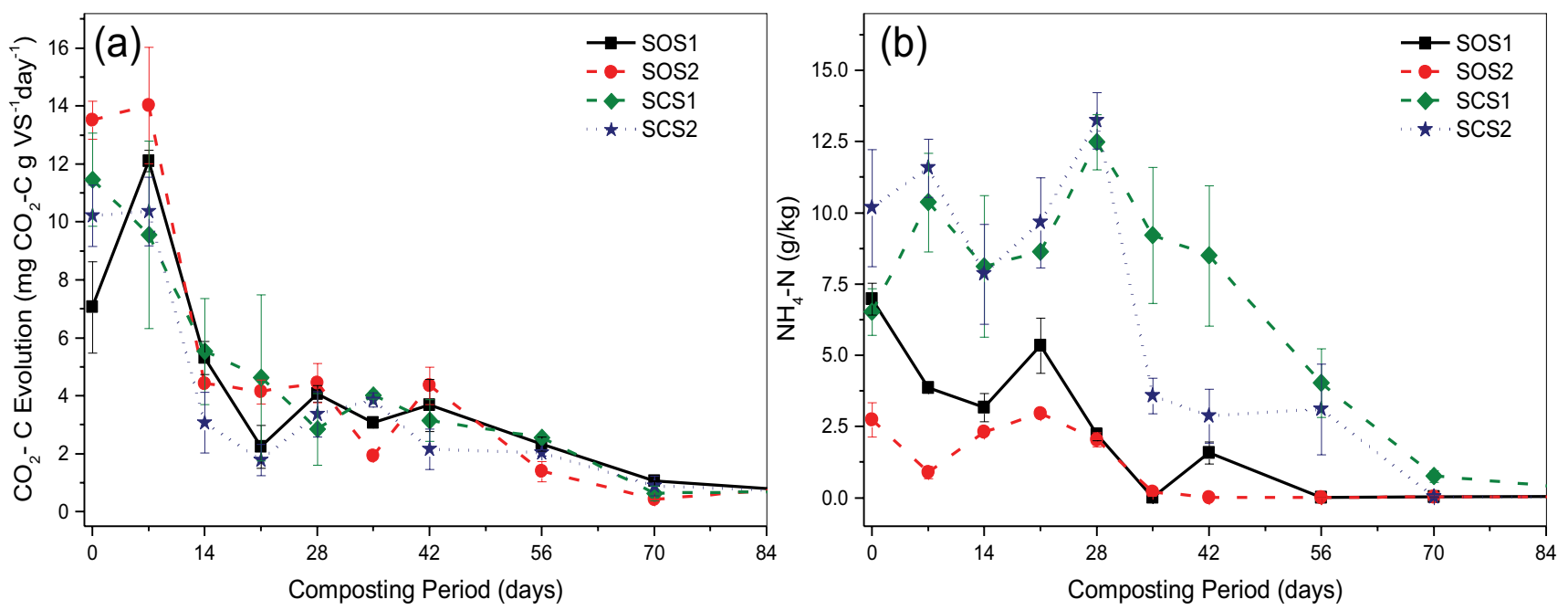

Fig. 4. Changes in (a) carbon dioxide respiration rate $\left(\mathrm{mg} \mathrm{CO}_{2}-\mathrm{C} \mathrm{g} \mathrm{VS}^{-1} \mathrm{day}^{-1}\right)$ and (b) ammonium-nitrogen $\left(\mathrm{NH}_{4}-\mathrm{N}\right)$ during the composting of FS with different organic waste type during the co-composting of faecal sludge with (a) chicken feather waste in a ratio of 1:2 - SCS1, (b) chicken feather waste in a ratio of 1:3 - SCS2, (c) organic market waste in a ratio of 1:2 - SOS1, and (d) organic market waste in a ratio of 1:3 - SOS2. Error bars represent the standard error for the duplicated piles.

from initial values of 7.1 and $13.5 \mathrm{mg} \mathrm{CO}_{2}-\mathrm{C} \mathrm{g} \mathrm{VS}^{-1} \mathrm{~d}^{-1}$ to peak values on the 7 th day. These then decreased gently but with slight fluctuations to final and stable values of 0.4 and $0.38 \mathrm{mg} \mathrm{CO}_{2}-\mathrm{Cg} \mathrm{VS}^{-1} \mathrm{~d}^{-1}$, respectively (Fig. 4a).

The initial increase in the $\mathrm{CO}_{2}-\mathrm{C}$ respiration rate exhibited by the SOS piles can be attributed to the existence of favourable conditions within these piles that may have favoured the growth, multiplication and activities of microorganisms [41]. It is important to note that all the composting piles recorded a sharp decrease in the $\mathrm{CO}_{2}-\mathrm{C}$ respiration rate during the early composting period of $1-2$ weeks, followed by a gentle decrease reaching stable values within 10-12 weeks composting period (Fig. 4a). This behaviour could be attributed to the rapid decomposition and depletion of organic carbon substances because of the early intensive microbial activities. The gradual and faster drop in the $\mathrm{CO}_{2}-\mathrm{C}$ respiration rate content to low concentrations also indicates that the organic matter had stabilised into humic-like substances and that it could no longer support the growth and activities of microorganisms [42]. The $\mathrm{CO}_{2}-\mathrm{C}$ results and evolution trends observed in this study are in accordance with those obtained in previous assays $[43,44]$. Detailed discussion on the evolution of $\mathrm{CO}_{2}-\mathrm{C}$ respiration rates observed in composting piles processing FS is presented in our previous work [30].

\subsection{Ammonium-nitrogen $\left(\mathrm{NH}_{4}-\mathrm{N}\right)$ evolution}

In Fig. $4 \mathrm{~b}$ it can be noted that $\mathrm{NH}_{4}-\mathrm{N}$ concentrations of SCS1 and SCS2 compost piles increased from initial values of 11.9 and $7.5 \mathrm{~g} \mathrm{~kg}^{-1}$ reaching peak values of 19.3 and $16.9 \mathrm{~g} \mathrm{~kg}^{-1}$, at day 7 during the thermophilic phase, respectively. These $\mathrm{NH}_{4}-\mathrm{N}$ concentrations remained considerably high in these piles for a period of approximately 56-70 d. Afterwards, they decreased sharply reaching generally stable final values of 0.05 and $0.06 \mathrm{~g} \mathrm{~kg}^{-1}$, respectively, after $98 \mathrm{~d}$ composting period. In contrast, the $\mathrm{NH}_{4}-\mathrm{N}$ concentration of
SOS1 and SOS2 dropped initially from 6.98 and $2.74 \mathrm{~g} \mathrm{~kg}^{-1}$ to 3.17 and $0.89 \mathrm{~g} \mathrm{~kg}^{-1}$ at day 14 and 7 , respectively; this then rose to mean values of 5.40 and $2.96 \mathrm{~g} \mathrm{~kg}^{-1}$, before it declined to low stable values of 0.01 and $0.02 \mathrm{~g} \mathrm{~kg}^{-1}$, after 56 and $42 \mathrm{~d}$ composting period, respectively.

All composting piles exhibited a rapid increase and high $\mathrm{NH}_{4}-\mathrm{N}$ concentrations, especially during the early composting stages. This can be attributed to the intensive microbial activities responsible for the rapid decomposition of nitrogen-containing organic molecules, leading to the production of $\mathrm{NH}_{4}-\mathrm{N}$. However, as the composting process progressed, all composting piles exhibited decreases in the $\mathrm{NH}_{4}-\mathrm{N}$ content, and finally, a gradual decrease reaching stable values in the range of $0.01-0.06 \mathrm{~g} \mathrm{~kg}^{-1}$ at the end of the composting period. This gradual decrease of $\mathrm{NH}_{4}-\mathrm{N}$, especially during the last stages of composting, could have been due to subsequent oxidation to $\mathrm{NO}_{3}-\mathrm{N}$ [32]. Detailed discussion on $\mathrm{NH}_{4}-\mathrm{N}$ evolution results observed in composting piles processing FS is presented in our previous work [30]. The $\mathrm{NH}_{4}-\mathrm{N}$ evolution trends observed in this study are similar to those published by Tam and Tiquia [45] during the composting of spent pig litter-sludge with sawdust.

\subsection{Viable Ascaris eggs inactivation efficiency}

All piles met the time-temperature criterion suggested by USEPA [3] for pathogen inactivation during composting. This criterion recommends that compost in windrows or piles should be subjected to temperatures $\geq 55^{\circ} \mathrm{C}$ for a minimum of $15 \mathrm{~d}$; with at least five turnings of the windrow during these high-temperature periods. In Fig. 5 it can be noted that the Ascaris eggs inactivation efficiency of the four types of composting piles differed significantly depending on the organic waste type and their mixing ratio. SCS1 and SCS2 piles (containing chicken feather waste) attained 100\% Ascaris eggs inactivation efficiency before the end of the thermophilic phase, within a composting period of about 


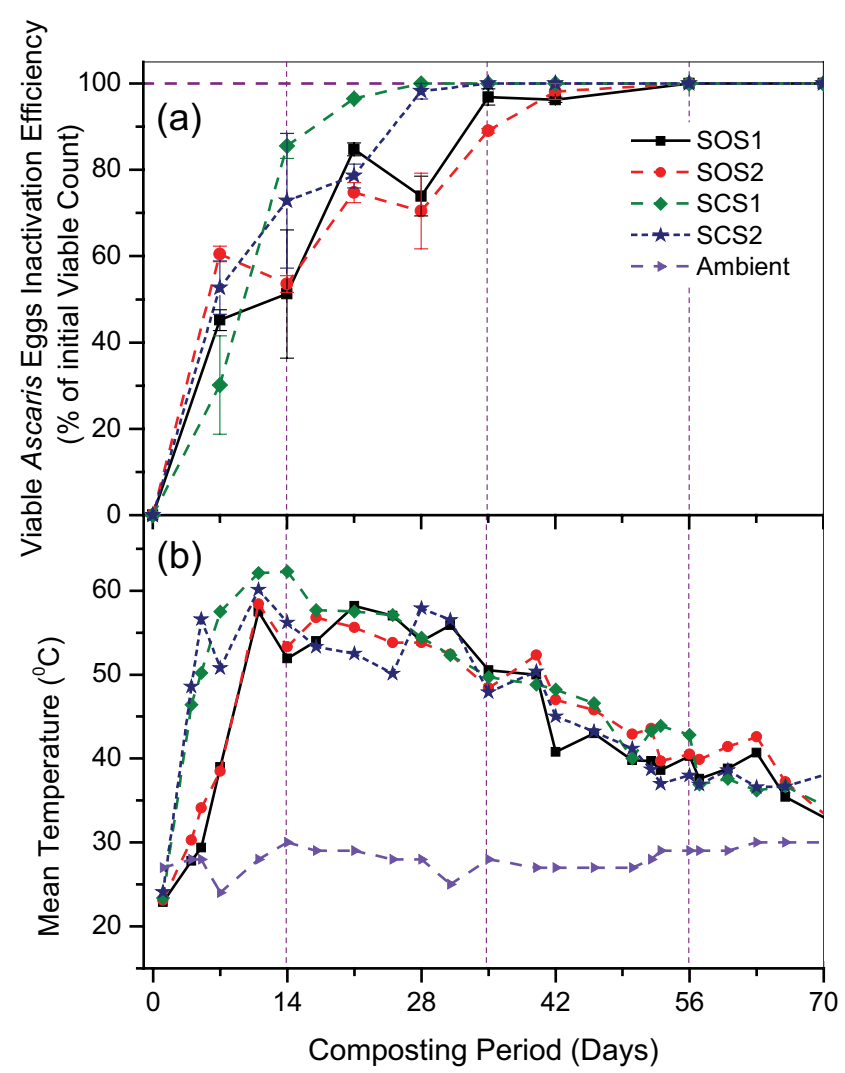

Fig. 5. Mean temperature evolution (b) and inactivation efficiency of viable Ascaris eggs (a) during co-composting of faecal sludge with different organic waste types. Error bars represent the standard error of $n=2$.

28 and $35 \mathrm{~d}$, respectively. However, SOS1 and SOS2 piles (containing organic market waste) attained about $96.3 \%$ viable Ascaris eggs inactivation efficiency by the end of the thermophilic phase of $42 \mathrm{~d}$, and this improved to $100 \%$ inactivation efficiency during maturation, after $56 \mathrm{~d}$ composting period. This further reduction in the viable Ascaris eggs during the maturation phase can be attributed to the positive consequences of damages triggered previously by higher composting temperature values during the thermophilic phase [5]. A similar behaviour was observed by Koné et al. [10], who attained $72 \%-88 \%$ helminth eggs inactivation during the thermophilic phase and finally $98 \%-100 \%$ inactivation during maturation phase, after 80 -d composting period.

The rapid viable Ascaris eggs inactivation efficiency exhibited by SCS piles (containing chicken feather waste) may have been due to the comparatively high lethal temperatures reached and sustained for an extended period in such piles (Figs. 2a and b). However, the longer viable Ascaris eggs survival periods exhibited by the SOS piles (containing organic market waste) may be attributed to the non-uniformity or uneven distribution of elevated temperatures within the whole mass of the composting piles especially during the early composting stages, given the heterogeneity nature of their composting feedstock that contained relatively large particles. This has also been pointed out by Wichuk and McCartney [6] as the common explanation of pathogen survival in composting piles. This study results suggest that co-composting of faecal sludge with chicken feather waste (SCS) and organic market waste (SOS) for a period of 5 and 8 weeks with temperatures of around $53^{\circ} \mathrm{C}-62.1^{\circ} \mathrm{C}$ and $50.7^{\circ} \mathrm{C}-58.7^{\circ} \mathrm{C}$ sustained in the composting piles for more than 3 and 5 weeks, respectively, using 7-d turning frequency, are sufficient for ensuring complete inactivation of viable Ascaris eggs in FS.

In the present study, Friedman test results revealed that the different organic waste types had a statistically significant effect ( $p=0.0001)$ on viable Ascaris eggs inactivation efficiency during FS composting. However, the mixing ratio of organic waste to faecal sludge did not show a significant effect on the Ascaris eggs inactivation efficiency. For comparison purposes, no publication could be found in literature that specifically evaluated the effect of organic waste mixing ratios on the inactivation efficiency of viable Ascaris eggs during composting. From Fig. 5 it can be seen that one of the most remarkable features of the results attained in the present study is the significant fluctuation in viable Ascaris eggs content especially in the piles containing organic market waste (SOS). Similar behaviour has been observed by Bean and Brabants [46] during the composting of similar feedstock. This odd phenomenon can be attributed to the high heterogeneity nature of the composting material and collected samples, especially during the early stages of composting where the composting material was observed to be very clumpy. It can be noted that FS did not mix thoroughly well with the organic market waste/chicken feather waste, despite the efforts made when setting up the composting piles. Therefore, depending on the samples collected and analysed, the viable Ascaris eggs content may have been considerably high if the sample consisted of high proportions of FS, and very low if it contained a high proportion of organic market waste or chicken feather waste. However, as the composting process progressed, the fluctuations in the Ascaris eggs content considerably reduced, which implies that the composting material had become generally homogeneous and therefore, the collected samples were more representative of the actual pathogens within the composting material.

\subsection{Temperature-time relationship}

Fig. 5 illustrates the evolution of mean composting temperatures and viable Ascaris eggs inactivation efficiency of the four composting piles. It can be seen that SCS piles (containing chicken feather waste) exhibited generally higher temperatures as well as faster Ascaris eggs inactivation efficiency compared with SOS piles (containing organic market waste). This clearly illustrates the importance of high temperature-time factor in inactivation of Ascaris eggs during composting. Szabová et al. [47] similarly found the high temperatures (of $>65^{\circ} \mathrm{C}$ ) to have been responsible for the faster inactivation of Ascaris suum within a period of only 4-5 d during the composting of sewage sludge with different organic waste on an industrial composting scale. Several studies have also reported temperature-time relationship as the major factor for pathogen die-off during composting $[3,6,48]$. However, it can be seen from Fig. 5 that 
although the Ascaris eggs inactivation efficiency of the four piles differed significantly, there was no significant difference observed in the composting temperatures evolution. Moreover, considering the mean temperature results of SOS and SCS piles for the periods when the Ascaris eggs were inactivated, it was noted that there existed a mean temperature difference of only $1.3^{\circ} \mathrm{C}-4.1^{\circ} \mathrm{C}$, which is considerably too small to cause such a significant difference in the Ascaris eggs survival periods of approximately 2-4 weeks. This strongly confirms that apart from thermal destruction, there are other mechanisms such as indigenous microbial activities, microbial antagonism, antibiotic action induced by certain actinomycetes and fungi, toxic by-products (mainly $\mathrm{NH}_{4}-\mathrm{N}$ ) produced during composting, etc. that may have partly been responsible for the significant difference in Ascaris eggs inactivation as well as their survival periods during FS composting.

In the present study, the potentially toxic by-products especially high $\mathrm{NH}_{4}-\mathrm{N}$ concentrations (Fig. 4b) resulting from the metabolic activities of the composting microorganisms were found to have partly been responsible for the inactivation of viable Ascaris eggs during FS composting. This observation was confirmed by highly significant inverse correlation observed between the evolution of $\mathrm{NH}_{4}-\mathrm{N}$ content and viable Ascaris eggs inactivation in SOS1 piles ( $p=0.0001, r=-0.832)$, SOS2 piles $(p=0.0001, r=-0.848)$ and SCS1 piles $(p=0.004, r=-0.592)$. It can be noted that the inactivation rate of viable Ascaris eggs varied depending on the level of $\mathrm{NH}_{4}-\mathrm{N}$ concentrations observed in the composting material, with SOC1 piles (containing chicken feather waste) which exhibited higher $\mathrm{NH}_{4}-\mathrm{N}$ concentrations attaining faster Ascaris eggs inactivation than SOS (market waste) piles. This implies that high $\mathrm{NH}_{4}-\mathrm{N}$ concentrations may lead to the release of free ammonia and other toxic by-products to Ascaris eggs in composting piles. This finding is also supported by Pecson et al. [49] who found ammonium concentrations $\left(0.2-5.0 \mathrm{~g} \mathrm{~L}^{-1}\right)$ to have been responsible for the significant inactivation of Ascaris eggs in sewage sludge at $\geq 40^{\circ} \mathrm{C}$ during the lab-scale experiment. They found the inactivation rate to have varied depending on the total ammonium concentration, $\mathrm{pH}$ value (7-12) and temperatures $\geq 40^{\circ} \mathrm{C}$. However, a significant correlation between Ascaris eggs inactivation and $\mathrm{NH}_{4}-\mathrm{N}$ evolution was not observed in some chicken feathers piles - that is, SCS2 piles ( $p=0.084, r=-0.378$ ). This could be attributed to the high temperatures observed in these piles, which may have masked the effects of $\mathrm{NH}_{4}-\mathrm{N}$ on the survival of Ascaris eggs in composting piles. Similarly, Pecson et al. [49] also found the effects of ammonium and $\mathrm{pH}$ on Ascaris eggs inactivation efficiency in sewage sludge to have been minimal at temperatures of $50^{\circ} \mathrm{C}$.

On the other hand, the inactivation of viable Ascaris eggs could also be explained by microbial antagonistic mechanisms or antibiotic action induced by indigenous microorganisms due to microbial competition or activities. This hypothesis was supported by Spearman's rho test, which revealed a statistically significant negative correlation (SOS1 $(p=0.0001, r=-0.899)$, SOS2 $(p=0.0001, r=-0.837)$, SCS1 $(p=0.0001, r=-0.727)$ and SCS2 $(p=0.003, r=-0.605))$ between viable Ascaris eggs inactivation efficiency and microbial competition or activities monitored by $\mathrm{CO}_{2}-\mathrm{C}$ respiration rate evolution (Fig. 4 a). This study results show that the Ascaris eggs inactivation rate varied depending on the level of microbial activities observed in the composting piles. SCS piles (containing chicken feather waste) where higher microbial activities were observed, attained faster Ascaris eggs than SOS (market waste piles). This suggests that the microbial antagonistic mechanisms or antibiotic action induced by indigenous microorganisms due to microbial competition or activities may have been responsible for Ascaris eggs inactivation in the composting material. Similar observations were made by Meekings et al. [50] who found the antagonistic mechanisms and antibiotic action resulting from the activities of indigenous microorganisms to have been responsible for the inactivation of Ascaris eggs in the compost aqueous. In their study, they found Ascaris eggs inoculated in the sewage sludge compost aqueous destroyed at very low temperatures $\left(30^{\circ} \mathrm{C}\right)$ whereas their viability still existed in the microorganism-free compost filtrate aqueous and distilled water at the similar temperatures.

In this study, three parameters were found to have equally played a significant role in the inactivation of viable Ascaris eggs during FS composting. However, using a multiple regression analysis, the effect of each mechanism on viable Ascaris eggs inactivation during composting was assessed (Table S2). On the whole, the regression results revealed temperature-time relationship as the most important factor that was responsible for the inactivation of viable Ascaris eggs during composting (with Beta $=-0.581$, $p=0.0001$ and $R^{2}=0.052$ ). This was followed by the indigenous microbial activities (measured by $\mathrm{CO}_{2}-\mathrm{C}$ respiration rate) that induce antibiotics or antagonistic effects (with Beta $=-0.427, p=0.0001$ and $R^{2}=0.072$ ); and lastly, high concentrations of $\mathrm{NH}_{4}-\mathrm{N}$ (measured as $\mathrm{NH}_{4}-\mathrm{N}$ evolution) released as a result of intensive microbial activities during composting (with Beta $=-0.253, p=0.003$ and $R^{2}=0.033$ ). This finding is of remarkable significance as it confirms the hypotheses frequently reported in literature review studies $[51,52]$ without substantial evidence from real field composting trials that pathogen inactivation during composting is not solely dependent on the temperature-time relationship factor. In the same vein, this study results suggest, therefore, that there is no single or universal mechanism that is solely responsible for pathogen inactivation during composting.

Overall, composting of FS with chicken feather waste reduced the viable Ascaris eggs inactivation periods from 8 weeks to about $4-5$ weeks, when compared with piles containing organic market waste. This represents approximately $42 \%$ reduction in the inactivation periods. This finding is of remarkable significance in the treatment of FS using composting in urban Africa, as it can reduce the capital and operational costs as well as the duration for treating a cubic meter of FS at the FS treatment facility by $42 \%$, which thus increase the capacity of the treatment plant by $42 \%$. The Ascaris eggs inactivation periods attained in this study are consistent with those published by Evans et al. [28] during the composting of similar feedstock, where complete helminth egg inactivation was attained with a composting period of 4-6 weeks. This study results suggest that co-composting of FS with a suitable organic waste for a period of 8 weeks with temperatures of around $50.7^{\circ} \mathrm{C}-58.7^{\circ} \mathrm{C}$ sustained in the composting piles for more than $31 \mathrm{~d}$, using $7 \mathrm{~d}$ turning frequency, is sufficient to 
ensure complete inactivation of viable Ascaris eggs in FS. Importantly, complete inactivation of the Ascaris eggs in the composting piles will additionally be dependent on exposing all the composting material to such temperatures for the recommended time, which implies that thorough mixing or sufficient turning of the piles is a very important factor for proper composting and compost sanitisation. The final compost attained in this study was hygienically safe for use in unrestricted agriculture as it was completely free from pathogen indicators.

\section{Conclusion}

This study aimed at investigating the fate of viable Ascaris eggs during the co-composting of FS with chicken feathers or organic market waste. Based on the study findings, the following conclusions can be drawn:

- Regardless of the type of organic waste co-composted with FS, all composting piles attained and sustained optimum temperatures $>55^{\circ} \mathrm{C}$ of effective pathogen inactivation for a period of more than 4 weeks.

- The organic waste types had a significant effect on the composting temperature evolution and viable Ascaris eggs inactivation efficiency. However, the mixing ratios of different organic waste with FS did not have a significant effect on the viable Ascaris eggs inactivation efficiency and composting temperature.

- The temperature-time factor was found to be the most important factor responsible for pathogen inactivation. However, other mechanisms such as microbial antagonistic mechanisms or antibiotic action induced by indigenous microorganisms and toxic by-products such as $\mathrm{NH}_{4}-\mathrm{N}$ also played an important role in the inactivation of viable Ascaris during composting.

- Composting piles containing chicken feathers exhibited the shortest Ascaris eggs survival periods of only 4 weeks compared with 6-8 weeks for those containing market wastes. Co-composting of dewatered FS with chicken feathers seems to be a promising low-cost FS treatment method in urban Africa, as it reduced the Ascaris eggs inactivation period by $42 \%$. This could thus increase the capacity of FS treatment plants or reduce their required capital investment, operational costs by $42 \%$.

- Co-composting of FS with a suitable organic waste for a period of 8 weeks with temperatures of around $50.7^{\circ} \mathrm{C}-58.7^{\circ} \mathrm{C}$ sustained in the composting piles for more than $31 \mathrm{~d}$, using $7 \mathrm{~d}$ turning frequency, is sufficient to ensure complete inactivation of Ascaris eggs in FS.

\section{Acknowledgements}

The authors would like to acknowledge the funding provided by the University of Leeds through the Leeds International Research Scholarship Award for Dr Musa Manga's PhD study. They also wish to express their sincere appreciation to National Water and Sewerage Corporation (NWSC) for offering them space for their experiment and laboratory works. The authors would also like to thank the research assistants Emma, Sharon, Aurah Kirabo and Asher Kigenyi. Lastly, they would like to thank Madam Julie,
Dr Irene Nansubuga, Dr Babu, Phyllis, Robinah and James Maiteki for the co-operation and support while at NWSC.

\section{References}

[1] A. Peal, B. Evans, I. Blackett, P. Hawkins, C. Heymans, Fecal sludge management (FSM): analytical tools for assessing FSM in cities, J. Water Sanition Hyg. Dev., 4 (2014) 371-383.

[2] U. Heinss, S.A. Larmie, M. Strauss, Solids Separation and Pond Systems for the Treatment of Septage and Public Toilet Sludges in Tropical Climate, Lessons Learnt and Recommendations for Preliminary Design, EAWAG/SANDEC Report No. 05/98, 1998.

[3] USEPA, Environmental Regulations and Technology: Control of Pathogens and Vector Attraction in Sewege Sludge (Including Domestic Septage) Under 40 CFR Part 503, in: EPA/625/R-92/013 United States Environmental Protection Agency, Office of Research and Development, National Risk Management Laboratory, Center for Environmental Research Information, Cincinnati, OH, Washington, D.C., 2003.

[4] C. Maya, F.J. Torner-Morales, E.S. Lucario, E. Hernández, B. Jiménez, Viability of six species of larval and non-larval helminth eggs for different conditions of temperature, $\mathrm{pH}$ and dryness, Water Res., 46 (2012) 4770-4782.

[5] R.G. Feachem, D.J. Bradley, H. Garelick, D.D. Mara, Sanitation and Disease: Health Aspects of Excreta and Wastewater Management, John Wiley \& Sons, New York, USA, 1983.

[6] K.M. Wichuk, D. McCartney, A review of the effectiveness of current time-temperature regulations on pathogen inactivation during composting, J. Environ. Eng. Sci., 6 (2007) 573-586.

[7] O. Cofie, D. Kone, S. Rothenberger, D. Moser, C. Zubruegg, Co-composting of faecal sludge and organic solid waste for agriculture: process dynamics, Water Res., 43 (2009) 4665-4675.

[8] A. Montangero, M. Strauss, Faecal Sludge Treatment, in, Eawag, Swiss Federal Institute of Aquatic Science \& Technology Sandec, Department of Water \& Sanitation in Developing Countries, Dübendorf, Switzerland, 2004

[9] M. Strauss, S.A. Larmie, U. Heinss, Treatment of sludges from on-site sanitation - low-cost options, Water Sci. Technol., 35 (1997) 129-136.

[10] D. Koné, O. Cofie, C. Zurbrügg, K. Gallizzi, D. Moser, S. Drescher, M. Strauss, Helminth eggs inactivation efficiency by faecal sludge dewatering and co-composting in tropical climates, Water Res., 41 (2007) 4397-4402.

[11] D.D. Cabañas-Vargas, E. de los Ríos Ibarra, J.P. Mena-Salas, D.Y. Escalante-Réndiz, R. Rojas-Herrera, Composting used as a low cost method for pathogen elimination in sewage sludge in Mérida, Mexico, Sustainability, 2013 (2013) 3150-3158.

[12] M. Manga, B.E. Evans, M.A. Camargo-Valero, N.J. Horan, Effect of filter media thickness on the performance of sand drying beds used for faecal sludge management, Water Sci. Technol., 74 (2016) 2795-2806.

[13] J.R. Okalebo, K.W. Gathua, P.L. Woomer, Laboratory Methods of Soil and Plant Analysis: A Working Manual, TSBF-CIAT and SACRED Africa, Nairobi, Kenya, 2002.

[14] D. Keeney, D. Nelson, Nitrogen-Inorganic Forms, A.L. Page, R.H. Miller, D.R. Keeney, Eds., Methods of Soil Analysis. Part 2. Chemical and Microbiological Properties, American Society of Agronomy and Soil Science Society of America, Madison, Wisoconsin, USA, 1982, pp. 643-698.

[15] R. Öhlinger, Soil Respiration by Titration, R. Öhlinger, F. Schinner, E. Kandeler, R. Margesin, Eds., Methods in Soil Biology, Springer-Verlag, New York, USA, 1996, pp. 95-98.

[16] K. Alef, Soil Respiration, K. Alef, P. Nannipieri, Eds., Methods in Applied Soil Microbiology and Biochemistry, Academic Press, London, UK, 1995, pp. 214-219.

[17] N.V. Hue, J. Liu, Predicting compost stability, Compos. Sci. Util., 3 (1995) 8-15.

[18] L.R. Cooperband, J.H. Middleton, Changes in chemical, physical and biological properties of passively-aerated cocomposted poultry litter and municipal solid waste compost, Compos. Sci. Util., 4 (1996) 24-34. 
[19] J.P.E. Anderson, Soil Respiration, A.L. Page, R.H. Miller D.R. Keeney, Eds., Methods of Soil Analysis. Part 2. Chemical and Microbiological Properties, American Society of Agronomy, Inc., Soil Science Society of America, Inc., Madison, 1984, pp. 831-866.

[20] A. Rühling, G. Tyler, Heavy metal pollution and decomposition of spruce needle litter, Oikos, 24 (1973) 402-416.

[21] A. García-Gómez, M.P. Bernal, A. Roig, Carbon mineralisation and plant growth in soil amended with compost samples at different degrees of maturity, Waste Manage. Res., 21 (2003) 161-171.

[22] D.M. Sullivan, R.O. Miller, Compost Quality Attributes, Measurements, and Variability, H.J. Stoffella, B.A. Kahn, Eds., Compost Utilization in Horticultural Cropping Systems, Lewis Publishers, New York, USA, 2001, pp. 97-120.

[23] C. Tognetti, M.J. Mazzarino, F. Laos, Improving the quality of municipal organic waste compost, Bioresour. Technol., 98 (2007) 1067-1076.

[24] P. Moodley, A. Collen, D. Hawksworth, L. Leibach, Standards Methods for the Recovery and Enumeration of Helminth Ova in Wastewater, Sludge, Compost and Urine-Diversion Waste in South Africa, Water Research Commission (WRC) Report No. TT322/08, University of KwaZulu-Natal, Pollution Research Group, Durban, South Africa, 2008.

[25] R.M. Ayres, D.D. Mara, Analysis of Wastewater for Use in Agriculture: A Laboratory Manual of Parasitological and Bacteriological Techniques, World Health Organisation, Geneva, 1996.

[26] L. Ash, R.T.C. Orihel, L. Savioli, M.A. Sin, A. Montresor, E. Renganathan, Training Manual on Diagnosis of Intestinal Parasites Based on the WHO Bench Aids for the Diagnosis of Intestinal Parasites in: WHO/CTD/SIP/98.2, Schistosomiasis and Intestinal Parasites Unit Division of Control of Tropical Diseases: World Health Organization, Geneva, 2004.

[27] J. Pallant, SPSS Survival Manual: A Step by Step Guide to Data Analysis Using IBM SPSS, Open University Press, London, UK, 2013.

[28] B. Evans, L.A. Fletcher, M.A. Camargo-Valero, S. Balasubramanya, C.K. Rao, S. Fernando, R. Ahmed, M.A. Habib, N.S.M. Asad, M.M. Rahman, K.B. Kabir, M.H. Emon, VeSV Value at the End of the Sanitation Value Chain, in: 53 p.: 29 fig., 17 tab., International Water and Sanitation Centre (IRC) and University of Leeds, Leeds, UK, 2015.

[29] B. Barda, D. Ianniello, H. Zepheryne, L. Rinaldi, G. Cringoli, R. Burioni, M. Albonico, Parasitic infections on the shore of Lake Victoria (East Africa) detected by Mini-FLOTAC and standard techniques, Acta Trop., 137 (2014) 140-146.

[30] M. Manga, B. Evans, M. Camargo-Valero, N. Horan, Nitrogen Evolution During Co-composting of Faecal Sludge with Chicken Feathers and Market Waste, 13th IWA Specialized Conference on Small Water and Wastewater Systems (SWWS) and 5th IWA Specialized Conference on Resources-Oriented Sanitation (ROS), 14-16th September 2016, Athens, Greece, 2016.

[31] D. Thyagarajan, M. Barathi, R. Sakthivadivu, Scope of poultry waste utilization, IOSR J. Agric. Vet. Sci., 6 (2013) 29-35.

[32] M. Manga, The Feasibility of Co-composting as an Upscale Treatment Method for Faecal Sludge in Urban Africa, Department of Civil Engineering, University of Leeds, Leeds, UK, 2017, Available at: http://etheses.whiterose.ac.uk/16997/.

[33] J. Ryckeboer, J. Mergaert, K. Vaes, S. Klammer, D. De Clercq, J. Coosemans, H. Insam, J. Swings, A survey of bacteria and fungi occurring during composting and self-heating processes, Ann. Microbiol., 53 (2003) 349-410.

[34] M. Tuomela, M. Vikman, A. Hatakka, M. Itävaara, Biodegradation of lignin in a compost environment: a review, Bioresour. Technol., 72 (2000) 169-183.
[35] G.A. Aydn, G. Kocasoy, Investigation of appropriate initial composition and aeration method for co-composting of yard waste and market wastes, J. Environ. Sci. Health., Part B, 38 (2003) 221-231.

[36] M.A. Bustamante, C. Paredes, F.C. Marhuenda-Egea, A. PérezEspinosa, M.P. Bernal, R. Moral, Co-composting of distillery wastes with animal manures: carbon and nitrogen transformations in the evaluation of compost stability, Chemosphere, 72 (2008) 551-557.

[37] Y. Lu, X. Wu, J. Guo, Characteristics of municipal solid waste and sewage sludge co-composting, Waste Manage., 29 (2009) 1152-1157.

[38] E.I. Stentiford, Composting and Compost, R.E. Hester, R.M. Harrison, Eds., Waste as a Resource, The Royal Society of Chemistry (RSC) Publishing, Cambridge, UK, 2013.

[39] P.H. Liao, L. Jones, A.K. Lau, S. Walkemeyer, B. Egan, N. Holbek, Composting of fish wastes in a full-scale invessel system, Bioresour. Technol., 59 (1997) 163-168.

[40] M. Finstein, F. Miller, P. Strom, Waste Treatment Composting as a Controlled System, W. Schoenborn, Ed., Biotechnology: A Comprehensive Treatise, Vol. 8, Microbial Degradation VCH Publication, New York, 1986, pp. 363-398 (Cited by Liao 1997).

[41] M.P. Bernal, J.A. Alburquerque, R. Moral, Composting of animal manures and chemical criteria for compost maturity assessment. A review, Bioresour. Technol., 100 (2009) 5444-5453.

[42] D. Said-Pullicino, F.G. Erriquens, G. Gigliotti, Changes in the chemical characteristics of water-extractable organic matter during composting and their influence on compost stability and maturity, Bioresour. Technol., 98 (2007) 1822-1831.

[43] M.C. Leconte, M.J. Mazzarino, P. Satti, M.C. Iglesias, F. Laos, Co-composting rice hulls and/or sawdust with poultry manure in NE Argentina, Waste Manage., 29 (2009) 2446-2453.

[44] M.P. Bernal, M.A. Sánchez-Monedero, C. Paredes, A. Roig, Carbon mineralization from organic wastes at different composting stages during their incubation with soil, Agric. Ecosyst. Environ., 69 (1998) 175-189.

[45] N.F.Y. Tam, S.M. Tiquia, Nitrogen transformation during co-composting of spent pig manure, sawdust litter and sludge under forced-aerated system, Environ. Technol., 20 (1999) 259-267.

[46] C. Bean, J. Brabants, Lab analyzes Ascaris ova recovery rates using revised protocols, Biosolids Tech Bull., 7 (2001) 12-14 (Cited by Gallizi, 2003).

[47] E. Szabová, P. Juriš, I. Papajová, Sanitation composting process in different seasons. Ascaris suum as model, Waste Manage., 30 (2010) 426-432.

[48] B. Vinnerås, A. Björklund, H. Jönsson, Thermal composting of faecal matter as treatment and possible disinfection methodlaboratory-scale and pilot-scale studies, Bioresour. Technol., 88 (2003) 47-54.

[49] B.M. Pecson, J.A. Barrios, B.E. Jiménez, K.L. Nelson, The effects of temperature, $\mathrm{pH}$, and ammonia concentration on the inactivation of Ascaris eggs in sewage sludge, Water Res., 41 (2007) 2893-2902.

[50] H.J. Meekings, E.I. Stentiford, D.L. Lee, The Effect of sewage sludge compost on the viability of the eggs of a parasitic nematode, Compos. Sci. Util., 4 (1996) 46-54.

[51] E. Stentiford, The Composting Process Applied to Sewage Sludge and Source Separated Refuse, D.V. Jackson, J.M. Merillot, P. L'Hermite, Eds., Composting and Compost Quality Assurance Criteria, Commission of the European Communities, Brussels, Belgium, 1992, pp. 69-80.

[52] E. Stentiford, M. de Bertoldi, Composting: Process, Solid Waste Technology \& Management, John Wiley \& Sons, Ltd., 2010, pp. 513-532. 


\section{Supplementary Information}

\section{Table S1}

Characteristics of raw material used ${ }^{a}$

\begin{tabular}{lllll}
\hline & Dewatered FS & Chicken feathers & Market waste & Sawdust \\
\hline $\mathrm{pH}(1: 10)$ & $7.96 \pm 0.15$ & $7.50 \pm 0.43$ & $8.25 \pm 0.49$ & $5.66 \pm 0.44$ \\
$\mathrm{EC} 27^{\circ} \mathrm{C}\left(\mathrm{Sm} \mathrm{cm}^{-1}\right)^{b} 1: 10$ & $2.12 \pm 0.42$ & $1.20 \pm 0.50$ & $3.08 \pm 0.32$ & $0.40 \pm 0.09$ \\
Moisture $(\%)$ & $68.71 \pm 3.80$ & $60.67 \pm 0.52$ & $63.35 \pm 3.32$ & $31.20 \pm 5.94$ \\
Organic matter $(\%)$ & $62.17 \pm 3.75$ & $56.50 \pm 4.95$ & $51.50 \pm 3.82$ & $94.30 \pm 2.97$ \\
Total organic Carbon ${ }^{b}(\%)$ & $33.83 \pm 1.41$ & $32.77 \pm 2.87$ & $31.25 \pm 3.89$ & $51.44 \pm 2.08$ \\
Total Kjeldahl N $(\%)$ & $3.35 \pm 0.29$ & $4.50 \pm 0.71$ & $1.67 \pm 0.33$ & $0.39 \pm 0.03$ \\
Nitrate- $\mathrm{N}^{b}\left(\mathrm{mg} \mathrm{kg}^{-1}\right)$ & $0.05 \pm 0.03$ & $0.04 \pm 0.01$ & $\mathrm{ND}$ & $\mathrm{ND}$ \\
Ammonium- $\mathrm{N}^{b}\left(\mathrm{mg} \mathrm{kg}^{-1}\right)$ & $0.53 \pm 0.39$ & $0.38 \pm 0.11$ & $0.08 \pm 0.00$ & $0.00 \pm 0.01$ \\
$\mathrm{C} / \mathrm{N}$ ratio & $10.11 \pm 4.94$ & $7.28 \pm 4.06$ & $18.77 \pm 11.70$ & $132.25 \pm 69.90$ \\
\hline
\end{tabular}

${ }^{a}$ Mean \pm Standard deviation (SD) of triplicates.

${ }^{b}$ Dry base.

$\mathrm{ND}=$ no detectable.

Table S2

Spearman's rho test results between viable Ascaris eggs survival and other mechanisms responsible for pathogen die-off during FS co-composting with different organic waste types

\begin{tabular}{lllll}
\hline & \multicolumn{2}{c}{$\mathrm{CO}_{2}-\mathrm{C}$ evolution $(n=22)$} & \multicolumn{2}{c}{$\mathrm{NH}_{4}-\mathrm{N}(n=22)$} \\
\cline { 2 - 4 } & $p$ & $r$ & $p$ & $r$ \\
\hline SOS1 & 0.0001 & -0.899 & 0.0001 & -0.832 \\
SOS2 & 0.0001 & -0.834 & 0.0001 & -0.848 \\
SCS1 & 0.0001 & -0.727 & 0.004 & -0.592 \\
SCS2 & 0.003 & -0.605 & $0.084^{a}$ & -0.376 \\
\hline
\end{tabular}

${ }^{a}$ Not significant.

Table S3

Mechanisms responsible for the inactivation of selected pathogen indicator (viable helminth eggs) during FS composting

\begin{tabular}{llll}
\hline $\begin{array}{l}\text { Pathogen Inactivation Mechanisms in the order } \\
\text { significance effect on pathogen inactivation }\end{array}$ & $\begin{array}{l}\text { Standardised } \\
\text { Coefficient (Beta) }\end{array}$ & Significant & $\begin{array}{l}R \text {-Square } \\
\text { Value }\end{array}$ \\
\hline Temperature & -0.581 & $0.0001^{a}$ & 0.052 \\
Microbial activities measured as $\mathrm{CO}_{2}-\mathrm{C}$ respiration rate & -0.427 & $0.0001^{a}$ & 0.072 \\
$\mathrm{NH}_{4}-\mathrm{N}$ Concentrations & -0.253 & $0.003^{a}$ & 0.033 \\
\hline
\end{tabular}

${ }^{a}$ Significant $(p<0.05)$. 